\title{
Growing Up With Capital Flows
}

\author{
Ashoka Mody ${ }^{\mathrm{a}, *}$ and Antu Panini Murshid ${ }^{\mathrm{b}}$ \\ ${ }^{a}$ Research Department, International Monetary Fund, 700 19th St. NW, Washington, D.C. 20431, USA \\ ${ }^{\mathrm{b}}$ Economics Department, University of Wisconsin-Milwaukee, Milwaukee, WI 53201,USA
}

February 4, 2004

\begin{abstract}
We examine the capital flows-domestic investment relationship for 60 developing countries from 1979 to 1999 . In the 1990s, even as liberalization attracted new flows, foreign capital stimulated less domestic investment than in the preceding decade. With greater financial integration, governments accumulated more international reserves and domestic residents diversified by investing abroad. Foreign investors were also motivated by diversification objectives rather than by unmet investment needs. Inflows were channeled increasingly through portfolio flows - or through foreign direct investment with the characteristics of portfolio capital—resulting in weak investment stimulus. However, stronger policy environments strengthened the link between inflows and investment.
\end{abstract}

Key words: Capital inflows, domestic investment, financial integration JEL classification: F21, F30

Forthcoming Journal of International Economics.

\footnotetext{
"Corresponding author: Tel.: + 1-202-623-9617; fax: +1-202-623-4740.

E-mail addresses: amody@imf.org (Ashoka Mody), amurshid@uwm.edu (Antu Panini Murshid)
} 


\section{Introduction}

In the 1990s, foreign capital flows were stepped up to developing countries as they relaxed their capital account restrictions (Figure 1). Since developing countries are thought to be short of capital, the new wave of inflows held the potential for raising investment significantly. But was that potential realized? This apparently simple question has received surprisingly little empirical attention.

An important study by Bosworth and Collins (1999) concluded that, on average, for the period 1978-1995, a dollar of external flows raised domestic investment by more than 50 cents; moreover, the foreign direct investment (FDI) component of external flows had an even stronger influence on host country investment. Here we build on their research by extending the time period of analysis to 1999 and examining how the capital flows-investment relationship has evolved over time. In particular, we consider whether that evolution can be explained by the degree of openness to international capital and by the quality of domestic policies.

We find that even as countries liberalized to attract new flows, the impact of foreign capital on domestic investment declined. This result seems surprising. If shortage of capital is a key defining characteristic of developing economies, why, then, did investment not increase? Our results suggest that either the availability of capital was not the binding developmental problem, as in many countries of East Asia, or the ability to absorb external capital into new investments was limited. Thus, much of the new wave of capital was diverted by governments into international reserves holdings or was offset by capital outflows as domestic investors diversified their portfolios. 
Foreign investors were also apparently motivated by diversification objectives rather than by significant unmet demand for investment financing. Portfolio flows, which increasingly became a more significant form of external financing for developing countries, have typically had a weak impact on domestic investment. At the same time, as FDI took on some of the characteristics of portfolio capital, its impact on investment also declined. Thus, in recent years traditional "greenfield" investments have given way to "mergers and acquisitions" as multinationals have focused on acquiring existing assets rather than making new investments.

While additional reserves, capital outflows, and shifts in the composition of longrun flows increasingly marginalized the importance of capital inflows as a source of investment-finance, our results also suggest that stronger policy environments tended to strengthen the capital flows-investment relationship. Clearly, the 1990s was a decade of transition —of growing up. Having opened their doors wider to international flows, developing countries faced the challenge of learning to handle and harness these flows. The remainder of this paper is organized as follows. Section 2 provides a brief theoretical overview of the foreign capital-domestic investment relationship. In section 3, we describe our empirical methodology and discuss the data. In section 4, we present our results, beginning with "base" regressions characterizing the relationship between the various components of long-term capital flows (FDI, bank lending, and portfolio flows) and domestic investment. We then briefly report the variations over time. Finally, we consider an "augmented" model that examines the extent to which the inter-temporal 
variation in the capital flows-investment relationship can be attributed to capital account openness and the quality of the policy environment. Section 5 concludes.

\section{Theoretical Overview and Hypotheses}

Governments often place capital controls in order to regulate capital inflows. These regulations are designed to direct capital into specific investment projects. For example, in many countries FDI is channeled into extractive industries and sovereign loans are intended to alleviate infrastructure bottlenecks. At the same time, capital controls are also designed to keep domestic savings within a country. This is not to say that residents do not find ways to take their savings abroad. However, since capital controls raise transactions costs, the scope for "capital flight" is limited. Thus capital controls may accentuate the relationship between capital inflows and domestic investment, either by funneling foreign-borrowing directly into specific investment projects or by deterring capital outflows. Moreover, in the presence of capital controls, central banks may feel less threatened by the possibility of sudden shifts in market sentiment and choose to maintain fewer reserves, so freeing up capital inflows for investment.

When an economy opens up to private capital flows, the impact on investment depends on the domestic investment environment and on the objectives of investors. Consider two different situations. First, if the marginal returns to capital are high in relation to the world rate of interest, substantial capital will enter the country and supplement domestic savings, leading to a strong relationship between foreign capital 
flows and domestic investment; such a relationship will persist during a transitional period while the risk-adjusted returns are relatively high. For instance, Blanchard and Giavazzi (2002) consider the opening of Greece and Portugal, in the context of their joining the European Monetary Union, and document significant capital inflows that financed increased investment and consumption.

A second case arises when an economy is open to capital inflows but domestic returns are low, or no higher than the world rate of interest. Foreign capital may still enter the country to achieve diversification (Kraay and Ventura 1999). But in this case, there can be no presumption that foreign capital inflows will boost domestic investment. Developing economies may fall in this category because the lack of complementary infrastructure lowers returns, as also advanced economies that have been open to capital flows and where risk-adjusted returns have been equalized.

It is important to distinguish across various types of foreign capital. Based on their specialized technical knowledge and market experience, FDI investors have an informational advantage over foreign portfolio investors as well as over other domestic investors. In Mody et. al. (2003), the informational advantage ("intangible capital") allows FDI investors to "outbid" other investor-types for the most productive opportunities, leading to more domestic investment relative to that undertaken by domestic investors or foreign portfolio investors in the same context. This effect is stronger when domestic productivity is higher, since FDI investors are now able to further leverage their specialized knowledge. However, the net effect of FDI on domestic investment will depend on the consequent decisions of domestic investors. If residual 
domestic investment opportunities offer low returns, domestic savings may be channeled out of the country in search of higher returns or lower risk.

But foreign investment may also "crowd in" domestic investment where it generates spillovers to the domestic economy. In Borenzstein et. al. (1998), such spillovers occur because foreign investments lower the costs of adopting new technologies, which in turn enhances the rate of growth. Other mechanisms may also operate, as when foreign investments generate demand for specialized inputs, thus increasing the marginal productivity of investments in those inputs. Spillovers are most likely to occur when knowledge can be rapidly transferred within the economy and domestic entrepreneurs are able to absorb that knowledge. While Borenzstein et. al. (1998) view human capital as the main conduit for achieving spillovers, we consider the possibility that the quality of country policies is the more general stimulus for spillovers.

\section{Methodology and Data}

We are interested in the influence of gross long-term capital inflows (measured as a fraction of GDP), $K_{i t}$, on domestic investment, $I_{i t}$ (also measured as a fraction of GDP). Our focus is on the within-country relationships and we employ the following specification:

$$
\text { (1) } I_{i t}=\alpha K_{i t}+\beta^{\prime} x_{i t}+\gamma I_{i t-1}+\varepsilon_{i t}
$$

where $i$ refers to each of the 60 countries in our sample (Table A1 lists the countries) and $t$ refers to the time period from 1979 to 1999 (our data begins in 1977 but we lose two years due to the use of lags in our estimation procedures, as discussed below). In the 
estimations, $K_{i t}$ represents either total capital flows or its components-FDI, loans and portfolio flows.

The controls, $x_{i t}$, are as follows: the growth rate of real GDP, the real interest rate, the cyclical variation in the ratio of M2 to GDP, a measure of GDP uncertainty, and the change in terms of trade (see Table A2 for a description of these variables). The growth rate of real GDP captures the important accelerator effect. The cost and availability of capital are proxied, respectively, by the real interest rate and the ratio of broad money to GDP separated from its three-year trend. Our measure of uncertainty is based on one-step ahead forecast errors for an AR(2) process in real GDP growth rates (as in Servén 1998). ${ }^{2}$ Finally the lagged value of investment, $I_{i t-1}$, is included as an additional control to allow for persistence in the dependent variable.

Two econometric issues arise in estimating such a model. First, causality may run from domestic investment to international capital inflows rather than the other way around. To deal with this concern, we need appropriate instruments to isolate the exogenous component of capital flows. Second, the presence of the lagged dependent variable on the right-hand side of our regressions may bias the coefficient estimates. To deal with these problems, we employ a number of different estimation strategies.

First, using annual data, we estimate a static investment equation with no lags of the dependent variable. First-differencing removes the influence of unchanging country characteristics. This is a useful benchmark, allowing comparison with the Bosworth and

\footnotetext{
${ }^{2}$ This is done separately for each country and recursively so that at any time, $t$, only the information in the sample up to time $t$ is utilized in our regressions.
} 
Collins (1999) estimates. While instrumental variable estimation reduces the reverse causality concern, the coefficients could be biased due to the presence of serial correlation in the data.

We experiment with a number of instruments, which proxy for shifts in the supply of capital flowing to developing countries. For instance, US interest rates and the phase of the US business cycle can be viewed as largely exogenous and at the same time important determinants of capital flows (Calvo et. al. 1993). Our preferred instrument however is a measure of the global pool of capital (of the particular type or in the aggregate) available to developing countries. This variable, suggested by Bosworth and Collins (1999), provides a more direct measure of the supply of global financial capital and reflects a broader set of external supply-side factors. ${ }^{1}$ We also consider an alternative instrument suggested by Tytell and Wei (2003): the weighted average of capital flows/GDP ratios to other countries in the same region; the weights are inversely related to the great circle distances between the largest two cities in any two countries. ${ }^{2}$ This regional variable is strongly correlated with capital flows into a given country, but, as with the measure of global capital flows to developing countries, is likely to be weakly correlated with the error terms. As additional instruments we include lagged values of all the endogenous variables including capital flows.

Second, we estimate a similar model, but using data averaged over three-year windows. Since the persistence in the three-year sample is weaker, issues arising on account of serial correlation are expected to be less important. Again, we remove country 
fixed-effects by first-differencing the data and correct for possible endogeneity using the instruments described above.

Third, we employ the dynamic panel estimator proposed by Arellano and Bond (1991) to estimate equation (1) using annual data. ${ }^{3}$ The Arellano-Bond estimator accounts for potential biases by employing a set of internal instruments for all endogenous and predetermined variables. These are simply an increasing sequence of lagged values of the endogenous and predetermined variables. In addition we employ the set of external instruments described above to capture the exogenous component of capital flows.

Our focus on data at higher (annual and three-year) frequencies than typically observed in the growth literature allows us to construct better instruments for two reasons. First, at higher frequencies the lagged capital flows variable should be a better predictor of current inflows. Second, if the full effect of a shock to investment occurs over an extended period of time, moving to higher frequencies should reduce feedback from investment to capital flows, thus mitigating the problem of reverse causality.

The capital flows data - all long-term capital flows and the components of longterm flows: foreign direct investment, commercial bank loans, portfolio flows_-are reported in the World Bank's Global Development Finance (GDF) on a gross basis, though net of amortizations on account of principal repayment. International Financial Statistics (IFS) provides an alternative data source on aggregate international resource flows that distinguishes between foreign investment, loans, and portfolio investments. The data source does not seem to impact the key results: the relationships reported in Bosworth and Collins (1999), based on IFS-data are also evident in the GDF-data. ${ }^{4}$ 
In addition to the control variables described above, in our "augmented specification," we include interaction terms between capital flows and a financial openness variable and capital flows and a policy variable. Our measure of financial openness is based on four proxies for government restrictions that impact capital mobility. These four measures, reported in the IMF's Exchange Arrangements and Agreements, characterize: (a) the openness of the capital account, (b) the openness of the current account, (c) the stringency of requirements for the repatriation and/or surrender of export proceeds, and (d) the existence of multiple exchange rates for capital account transactions. For each variable, a one indicates a relatively open regime and a zero otherwise. ${ }^{5}$ We construct an index of financial integration as the sum of these four measures of government-restrictions. Thus our index takes values between zero and four, where a zero indicates that a country has closed capital and current accounts, places restrictions on its export receipts and further operates a system of multiple exchange rates, and a value of four indicates an open regime. ${ }^{6}$ This index, which was first introduced in a systematic dataset by Grilli and Milesi-Ferretti (1995), is a graded measure of a country's financial integration with the rest of the world, consolidating the capital account restrictions dummy with other measures relating to the ability of investors to bypass controls on the capital account. ${ }^{7}$

Our measure of policy is the World Bank’s Country Policy Institutional Assessment (CPIA) Index. This index provides an assessment of how conducive a country's current policy and institutional framework are to fostering poverty reduction and sustained growth. The overall rating is based on 20 indicators that fall into one of 
five categories: economic management, structural reform, social inclusion and public sector management and institutions. Each indicator receives a 5\% weight in the overall rating. ${ }^{8}$ The resulting index varies from $0-5$ : countries with poor polices are rated at the lower end and those with better policies take on higher values.

\section{The Capital Flows-Investment Relationship}

We begin by presenting the static specification of the investment equation, with the data observed annually and the instruments for endogeneity as discussed above. As with all of our regressions, unchanging country-specific heterogeneity is removed by first differencing the data. The results reported in column (1) of Table 2 indicate that, on average, each dollar of long-run flows raised domestic investment by 66 cents in our sample of countries. This result is similar to that obtained by Bosworth and Collins (1999), who found that an additional dollar of total inflows to developing countries raised investment by 52 cents. ${ }^{9}$ By contrast a similar analysis conducted for a sample of industrialized countries showed no relationship between foreign capital flows and domestic investment. This is consistent with the earlier discussion that the domestic investment and financing decisions become increasingly dissociated as economic and financial integration with the rest of the world increases. ${ }^{10}$

In column (2) we re-estimate our investment equation using three-year averages. The results are largely unchanged. Long-run capital inflows continue to reveal a statistically significant and sizeable impact on domestic investment. These three-year data have the advantage that they are less persistent than the annual series, which is clear 
from the test of second order serial correlation. ${ }^{11}$ The disadvantage is that feedback from domestic investment to capital inflows is likely to be more pronounced.

In column (3) we consider a dynamic investment equation, which is estimated using annual data. This is a more direct approach of addressing the issue serial correlation without introducing the risk of picking up stronger feedback effects. We estimate this specification using the first-difference one-step GMM-estimator developed by Arellano and Bond (1991). In column (4), we include the additional controls: GDP growth, the real interest rate, the deviation in M2 from trend, GDP uncertainty, and the change in terms of trade. Each variable except for the shock to terms of trade is treated as endogenous; hence two-period lagged-levels for each of these variables are used as instruments along with global long-run flows to developing countries.

The dynamic specification results suggest that the short-run impact of a dollar of long-term flows is to raise investment by between 32 and 44 cents. The strong persistence in investment implies that the long-run impact on investment is considerably higher, ranging from between $118(=0.32 /[1-0.729])$ and $150(=0.44 /[1-0.707])$ cents. Following an improvement in terms of trade, investment appears to fall. The real interest is negatively associated with investment; however this result is weak. A stronger relationship is found between the trend-deviation in M2, suggesting that this variable is perhaps better able to capture changes in the user cost of capital. Our measure of uncertainty is found to negatively impact on investment; the result is borderline significant and consistent with the results in Servén (1998). 
Arellano and Bond (1991) suggest two tests to assess the validity of dynamic specifications. Crucially, second-order serial correlation should be absent and the results meet that test. They also suggest a Sargan test for over-identifying restrictions. In columns (3) and (4), the null of the validity of over-identifying restrictions is rejected. However, it is well-known that in finite samples the Sargan test statistics obtained from the one-step Arellano-Bond estimator often over-reject the null in the presence of heteroskedasticity (see Arellano and Bond 1991). While standard errors robust to heteroskedasticity can be obtained, the distribution of the Sargan test is unknown in this case. Thus the Sargan test statistic reported for the one-step estimator should be treated with caution. For this reason, researchers sometimes rely on the Sargan test statistics from the two-step estimator, which in this case does not lead to a rejection of the null hypothesis that the over-identifying restrictions are in fact valid.

Next, in Table 3, we repeat the same analysis as in Table 2, for FDI, loans, and portfolio capital. The results from the annual and three-year average static models presented in columns (1) and (2) suggest that FDI had the strongest impact on domestic investment; each dollar of new inflows raised investment by an amount between 72 and 86 cents. Bank loans have had a somewhat lower, but nevertheless sizeable impact, with each additional dollar of foreign loans raising domestic investment by a little over half the amount of the loan received. Portfolio flows also seem to have had an impact on domestic investment; however, this result is significant at only the 10 percent level. The test statistics reported for columns (1) and (2) are encouraging. The Sargan test for the validity of the over-identifying restrictions cannot be rejected in either case. While tests 
for second-order serial correlation reveal persistence in the annual data, it is clearly lower in the three-year data.

Column (3) reports the results using a dynamic specification. The coefficients are broadly consistent with those reported in columns (1) and (2). FDI continues to show a strong and statistically significant impact on domestic investment. In the short-run an additional dollar of foreign investment appears to raise domestic investment by 51 cents. The persistence in investment implies that this impact is significantly amplified over the long-run. However, the influence of loans falls sharply in the dynamic specification and that of portfolio flows turns negative, though this result is only borderline statistically significant. The contrast in the results with respect to portfolio flows between static and dynamic specifications suggests that prior years of higher investment are associated with new inflows of portfolio capital. The implication is not that portfolio capital is "suckedin" to finance new investment opportunities; rather new inflows enter only to acquire a stake in a larger stock of existing assets. The goal of such investments, which take place at arm's length, is presumably for the purpose of international diversification.

Prior to the debt crisis of the early 1980s, loans were the largest component of long-run flows to developing countries. Starting in the mid-1980s, FDI became the dominant form of foreign capital but by the 1990s portfolio investors had also become major players in emerging markets. The 1990s were also a period of policy change for many developing countries. Restrictions on financial systems were reduced and product and capital markets were opened up to foreign competition. At the same time, greater 
emphasis was placed on curbing domestic budgetary and monetary profligacy and on building stronger institutional foundations for growth.

In order to explore the impact of these changes, we re-estimate equation (4) of Table 2 using a 10-year window of data rolled forward through time. The long-run impact of aggregate inflows, calculated by normalizing the coefficient on total flows by the coefficient on lagged investment, is plotted in Figure 2. It is evident that the long-run relationship between foreign capital flows and domestic investment declined sharply over time.

The changes over time in the coefficient estimates for the components of capital inflows are reported in columns (4) and (5) of Table 3. The results suggest striking differences in the impact of each type of financial capital across the two periods. In the 1980s, it would appear that both FDI and loans had a large impact on domestic investment. Over this period, developing countries received large quantities of both types of flows. By contrast there is no evidence of a link between portfolio capital and domestic investment. However, since the amount of portfolio capital flowing to developing countries was negligible, it would appear, overall, that external flows played an important role in financing domestic investment.

In the 1990s, the link between portfolio flows and domestic investment strengthened somewhat, while the impact of FDI and loans fell. These results are not altogether surprising. The declining impact of foreign direct investment may reflect a shift in the composition of FDI, away from the traditional "greenfield" variety toward more mergers and acquisitions. Arguably foreign acquisitions could lead to capital 
formation indirectly since newly acquired firms often go through significant restructuring and also because the original shareholders may reinvest in other sectors. It does not appear, however, that either of these effects was important. It is somewhat less clear why the impact of loans declined so drastically in the 1990s. It could be the consequence of a shift from public- to private-sector borrowing. Prior to the debt crisis, the public sector was responsible for the bulk of new borrowing financed by banks. Often these loans were funneled into large scale investment projects. In the aftermath of the crisis, loans fell in importance. Lending which continued went largely to the private sector, which possibly used foreign loans as a substitute for more expensive domestic borrowing.

Thus, our results suggest that in the 1990s, as many countries experienced increased capital inflows, the marginal impact of inflows on domestic investment declined. This is consistent with the observation reported in Table 1 that capital inflows were also accompanied by increases in reserves and outflows following greater financial openness. However at the same time, improvements in the policy environment created new opportunities for domestic investment and reduced uncertainties regarding the macroeconomic environment. This generated additional incentives for developing country capital to stay at home, which may have offset, in part, the effects of increased financial openness.

In Table 4, we explicitly consider the importance of financial integration and domestic policies by allowing the coefficient on capital flows to be a function of these variables. Columns (1) and (4) of Table 4 report the importance of such interactions when foreign capital takes the form of FDI. Column (1) presents the results from a dynamic 
specification using annual data, while the regression in column (4) utilizes a static specification with the three-year averages. The results suggest that greater financial integration weakens the impact of FDI on investment. This is consistent with our earlier finding, which showed that the link between FDI and domestic investment declined in the 1990s. It is also consistent with other evidence that FDI has a strong (essentially one-toone relationship) with investment in Sub-Saharan Africa, where most countries still have relatively closed capital accounts, but a weaker impact in Latin America and East Asia, where countries are generally more integrated (see Agosin and Mayer 2000). The interactions between portfolio flows and openness are similar, although the results are not statistically significant (columns (3) and (6)). The positive interaction between loans and financial integration in the dynamic specification (column (2)) is at variance with the results with the three-year averages, which show a negative relationship as with the other flows (column (5)).

Interactions with our policy variable suggest that the link between capital flows and investment strengthens following improvements in the policy environment. In countries with a CPIA-rating exceeding 3.5 (the top 20th percentile in our sample), additional flows have a stronger impact on investment. This is especially true of FDI, but also in the case of portfolio flows. For portfolio flows, the absolute size of the coefficient on the interaction term is approximately four times higher than the coefficient on the interaction with financial openness (for both annual and three-year estimates); and thus liberalization and policy-quality, though offsetting each other, may, in sum, have favored an increased impact of portfolio flows on domestic investment. 
Sensitivity analysis (not shown here) suggested qualitatively similar findings when using different measures of financial integration and policy. The stock of external assets and liabilities of foreign direct and portfolio investment divided by GDP was used as an alternative measure of financial openness, ${ }^{12}$ while the ICRG economic risk rating replaced the CPIA variable.

\section{Conclusions}

A potentially important benefit of foreign capital inflows into developing economies is the augmentation of investment resources to add to capital stock with high marginal returns. However, as the paper's theoretical discussion shows, financial integration allows agents to optimize their investment portfolios, and this may not involve increasing domestic investment. The results of this paper suggest that the surge in capital flows during the 1990s was driven largely by this diversification motive.

Countries with better policies did have greater success in absorbing foreign inflows. At least in part, this could be because improved policies raised the marginal product of new investments, while at the same time they created an environment conducive for the diffusion of new technologies and ideas intrinsic to foreign capital. Improved policies probably also reduced the risk of holding domestic assets, which in turn, by discouraging capital outflows, would have further enhanced the relationship between capital flows and investment. 
Table A1: Country List

\begin{tabular}{|c|c|}
\hline East Asia and the Pacific & South Asia \\
\hline Fiji & Bangladesh \\
\hline Indonesia & India \\
\hline Korea, Rep. & Nepal \\
\hline Malaysia & Pakistan \\
\hline Papua New Guinea & Sri Lanka \\
\hline Philippines & Sub-Saharan Africa \\
\hline Thailand & \multirow{4}{*}{$\begin{array}{l}\text { Benin } \\
\text { Burkina Faso } \\
\text { Burundi } \\
\text { Central African Republic }\end{array}$} \\
\hline Latin America and the Caribbean & \\
\hline Argentina & \\
\hline Belize & \\
\hline Bolivia & Chad \\
\hline Brazil & \multirow{2}{*}{$\begin{array}{l}\text { Cote d'Ivoire } \\
\text { Gambia, The }\end{array}$} \\
\hline Chile & \\
\hline Colombia & \\
\hline Costa Rica & Kenya \\
\hline Dominican Republic & Malawi \\
\hline Ecuador & Mali \\
\hline Grenada & Mauritania \\
\hline Guatemala & Mauritius \\
\hline Guyana & Niger \\
\hline Jamaica & Nigeria \\
\hline Mexico & Rwanda \\
\hline Peru & Senegal \\
\hline St. Vincent and the Grenadines & Seychelles \\
\hline Trinidad and Tobago & Sierra Leone \\
\hline Uruguay & \multirow{2}{*}{$\begin{array}{l}\text { South Africa } \\
\text { Uganda }\end{array}$} \\
\hline Middle East and North Africa & \\
\hline Algeria & Zambia \\
\hline Egypt, Arab Rep. & \multirow[t]{6}{*}{ Zimbabwe } \\
\hline Jordan & \\
\hline Morocco & \\
\hline Syrian Arab Republic & \\
\hline Tunisia & \\
\hline Turkey & \\
\hline
\end{tabular}


Table A2 Descriptions of Variables and Data Sources:

\begin{tabular}{|c|c|}
\hline Variable & - \\
\hline Investment & $\begin{array}{l}\text { Gross domestic fixed capital divided by GDP. Missing values were } \\
\text { extrapolated based on gross domestic investment. Source: World Development } \\
\text { Indicators, NE.GDI.FTOT.ZS. }\end{array}$ \\
\hline \multirow[t]{2}{*}{ Growth rate } & $\begin{array}{l}\text { Annual growth of real GDP at market prices. Source: World Development } \\
\text { Indicators, NY.GDP.MKTP.KD.ZG. }\end{array}$ \\
\hline & $\begin{array}{l}\text { Change in terms of trade: Log difference in net barter terms of trade. Missing } \\
\text { values were interpolated. Source: World Development Indicators, } \\
\text { NE.TRM.TRAD.XU. }\end{array}$ \\
\hline \multicolumn{2}{|c|}{$\begin{array}{l}\text { Real interest rate Short-term nominal interest rate minus inflation rate. Short-term interest rates } \\
\text { refer to lending rates, otherwise money market rates or discount rates. Source: } \\
\text { International Financial Statistics CD ROM series } 60,60 \mathrm{~B} \text {, and } 60 \mathrm{M} \text {. }\end{array}$} \\
\hline Broad money & $\begin{array}{l}\text { Deviation in M2/GDP from three-year trend. Source: World Development } \\
\text { Indicators, FM.LBL.MQMY.GD.ZS. }\end{array}$ \\
\hline 011 & . Country Policy Institutional Assessment Index. Source: World Bank. See text. \\
\hline $\begin{array}{l}\text { inancial } \\
\text { ategration }\end{array}$ & Arrangements and Agreements. See text. \\
\hline \multicolumn{2}{|c|}{$\begin{array}{l}\text { Long-term flows Gross private flows net of amortizations on account of principal repayment. } \\
\text { Data were normalized by GDP. Source: Global Development Finance (2001), } \\
\text { DT.NFA.PRVT.CD }\end{array}$} \\
\hline oreign direct & $\begin{array}{l}\text { Foreign direct investment divided by GDP. Source: Global Development } \\
\text { Finance (2001), BX.KLT.DINV.CD. }\end{array}$ \\
\hline La & $\begin{array}{l}\text { Sum of PPG and PNG loans from private banks and other private financial } \\
\text { institutions divided by GDP. Source: Global Development Finance (2001), } \\
\text { DT.NFL.PCBK.CD and DT.NFL.PNGC.CD. Missing values filled using IFS } \\
\text { data, when these data were unavailable, missing values were interpolated. }\end{array}$ \\
\hline Portfolio & $\begin{array}{l}\text { Sum of bond and equity investments, divided by GDP. Source: Global } \\
\text { Development Finance (2001), BX.PEF.TOTL.CD.DT and DT.NFL.BOND.CD. } \\
\text { Missing values filled using IFS, when these data were unavailable, missing } \\
\text { values were interpolated. }\end{array}$ \\
\hline $\begin{array}{l}\text { Global capital } \\
\text { flows }\end{array}$ & $\begin{array}{l}\text { Sum of gross long-run flows to our sample of countries divided by the GDP } \\
\text { aggregated across our sample. A similar variable was calculated for FDI, bank }\end{array}$ \\
\hline $\begin{array}{l}\text { Regional capital } \\
\text { lows }\end{array}$ & $\begin{array}{l}\text { Weighted average of capital flows relative to GDP in other countries in the } \\
\text { same region. See text. A similar variable was calculated for FDI, bank loans } \\
\text { and portfolio flows. }\end{array}$ \\
\hline
\end{tabular}




\section{Acknowledgements}

This paper was initiated as background to Chapter 3 of the World Bank's Global Development Finance 2001. Our special thanks go to Barry Bosworth, Peter Clark, Antonio Spilimbergo, two anonymous referees, and the editor, Charles Engel, for their valuable substantive and editorial comments. We thank Jean Skidmore for exceptionally patient research assistance. The views expressed in the paper are those of the authors and should not be attributed to the International Monetary Fund. 


\section{References}

Agosin, M.R., Mayer, R., 2000. Foreign investment in developing countries. Does it crowd in domestic investment? UNCTAD Paper 146.

Anderson, T.W., Hsiao, C., 1982. Estimation of dynamic models with error components. Journal of the American Statistical Association 76, 598-606.

Arellano, M., Bond, S.R., 1991. Some tests of specification for panel data: Monte Carlo evidence and an application to employment equations. Review of Economic Studies 58, 277-97.

Blanchard, O., Giavazzi, F., 2002. Current account deficits in the euro area: the end of the Feldstein-Horioka puzzle? Brookings Papers on Economic Activity 2, 147-210.

Boisso, D., Ferrantino, M., 1997. Economic distance, cultural distance, and openness: empirical puzzles. Journal of Economic Integration 12, 456-484.

Borenzstein, E., De Gregorio, J., Lee, J-W., 1998. How does foreign direct investment affect growth? Journal of International Economics 45, 115-135.

Bosworth, B., Collins, S.M., 1999. Capital flows to developing economies: implications for saving and investment. Brookings Papers on Economic Activity 1, 143-169.

Calvo, G., Leiderman, L., Reinhart, C., 1993. Capital inflows to Latin America: the role of external factors. IMF Staff Papers 40, 108-151.

Chinn, M., 2002. The compatibility of capital controls and financial development: a selective survey and empirical evidence. Santa Cruz Center for International Working Papers 02-10.

Grilli, V., Milesi-Ferretti, G.M., 1995. Economic effects and structural determinants of capital controls. International Monetary Fund Staff Papers 42, 517-551.

International Monetary Fund. International Financial Statistics. IMF, Washington.

International Monetary Fund. Exchange Arrangements and Agreements. IMF, Washington.

International Monetary Fund, 2001. World Economic Outlook. IMF, Washington.

Kraay, A., Ventura, J., 1999. Current accounts in debtor and creditor countries. The Quarterly Journal of Economics 115, 1137-1166. 
Lane, P., Milesi-Ferretti, G.M., 2002. International financial integration. Working Paper prepared for the IMF Third Annual Research Conference.

Mody, A., Razin, A., Sadka, E., 2003. The role of information in driving FDI flows: host-country transparency and source country specialization. Forthcoming IMF Working Paper.

Quinn, D., 1997. The correlates of change in international financial regulation. American Political Science Review 91, 531-551.

Servén, L., 1998. Macroeconomic uncertainty and private investment in developing countries: an empirical investigation. World Bank Policy Research Working Paper 2035.

Servén, L., Solimano, A., 1993. Striving for growth after adjustment: the role of capital formation. World Bank, Washington.

Tytell, I., Wei, S-J., 2003. Does financial globalization induce better macroeconomic policies? Forthcoming IMF Working Paper.

World Bank, 2001. Global Development Finance. World Bank, Washington.

World Bank. World Development Indicators. World Bank, Washington. 
Table 1 Composition and Uses of Private Long-Term Flows: 1977-1999 (\$US billion)

\begin{tabular}{|c|c|c|c|c|c|c|}
\hline & & $77-79$ & $80-84$ & $85-89$ & $90-94$ & $95-99$ \\
\hline \multicolumn{7}{|c|}{ Composition of flows } \\
\hline & Private long-term flows & 39.4 & 47.0 & 31.6 & 109.3 & 256.9 \\
\hline & FDI & 6.6 & 8.7 & 15.3 & 52.7 & 154.6 \\
\hline & Loans & 25.0 & 29.2 & 5.4 & 7.3 & 27.0 \\
\hline & Portfolio & 2.4 & 1.8 & 3.6 & 41.8 & 74.8 \\
\hline & Other (debt flows) & 5.3 & 7.3 & 7.2 & 7.5 & 0.5 \\
\hline \multirow[t]{4}{*}{ Use of funds } & Total resource flows & 81.9 & 93.8 & 83.5 & 195.0 & 330.9 \\
\hline & Current account deficit & 26.9 & 49.1 & 40.2 & 81.5 & 93.5 \\
\hline & Change in reserves & 26.7 & -6.0 & 6.0 & 48.6 & 69.3 \\
\hline & Capital outflows and E\&O & 28.4 & 50.7 & 37.2 & 64.9 & 168.1 \\
\hline
\end{tabular}

Source: World Bank. Global Development Finance, 2001

Notes: Data on the composition of flows start in 1977, while data on the use of funds start in 1978. 
Table 2 Capital Flows-Investment Relationship: 1979-1999

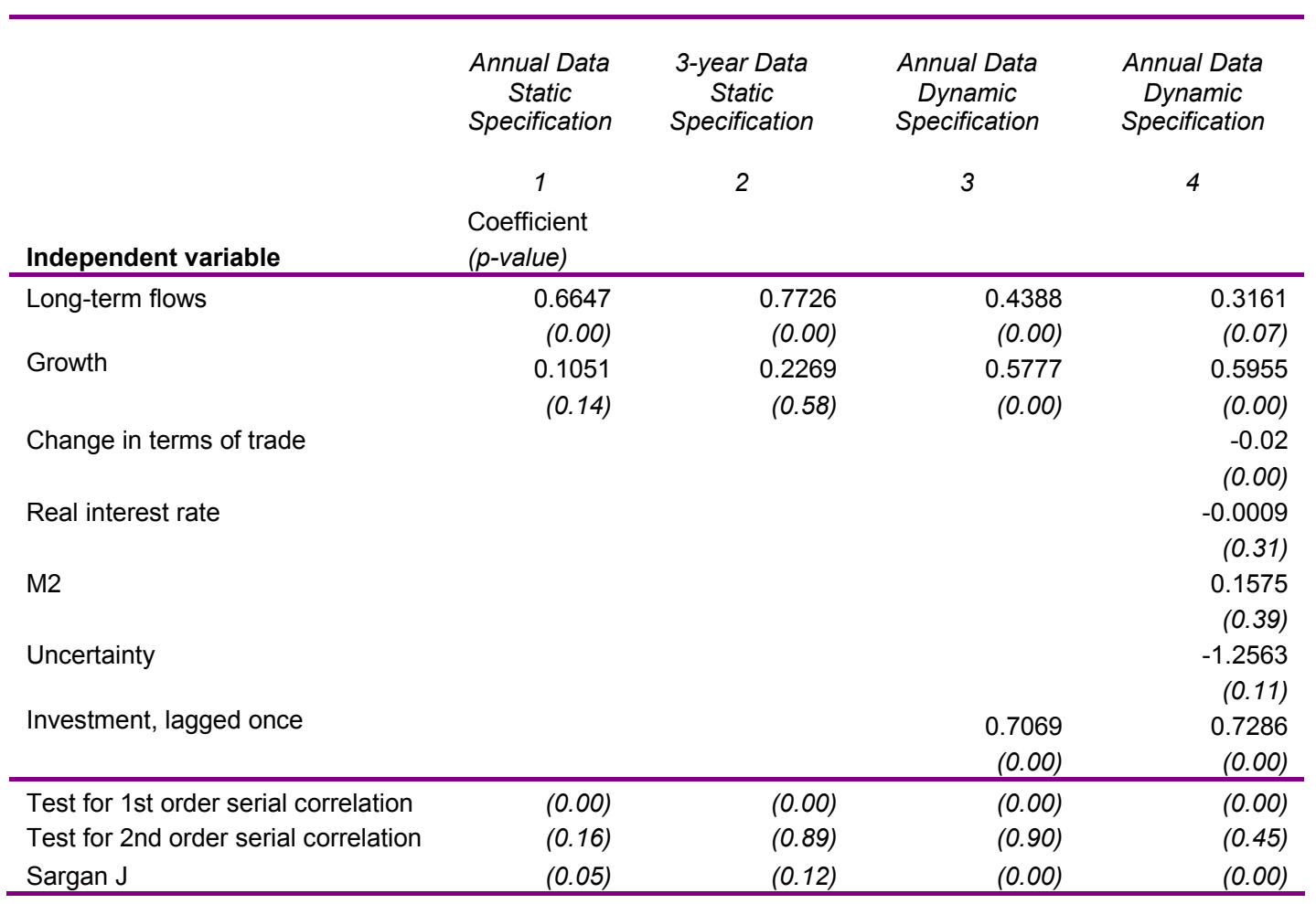

Notes. For each column p-values are reported in brackets. Regressions 1 and 2 were estimated using an instrumentals variables estimator. Columns 3-4 were estimated using the Arellano-Bond (1991) one-step first-difference GMM estimator, using DPD98 for Gauss. The coefficients and p-values are robust to heteroscedasticity. . 
Table 3 Capital Flows-Investment Relationship, By Type and Changes Over Time: 19791999

\begin{tabular}{|c|c|c|c|c|c|}
\hline & \multirow{2}{*}{$\begin{array}{l}\text { Annual Data } \\
\text { Static } \\
\text { Specification }\end{array}$} & \multirow{2}{*}{$\begin{array}{c}\text { 3-year Data } \\
\text { Static } \\
\text { Specification }\end{array}$} & \multicolumn{3}{|c|}{ Annual Data Dynamic Specification } \\
\hline & & & Full Sample & 1980s & $1990 s$ \\
\hline Independent variable & \begin{tabular}{l}
1 \\
\multicolumn{1}{c}{1} \\
Coefficient \\
(p-value)
\end{tabular} & 2 & 3 & 4 & 5 \\
\hline Foreign direct investment & $\begin{array}{r}0.7204 \\
(0.00)\end{array}$ & $\begin{array}{r}0.8626 \\
(0.00)\end{array}$ & $\begin{array}{r}0.5138 \\
(0.05)\end{array}$ & $\begin{array}{r}0.9363 \\
(0.07)\end{array}$ & $\begin{array}{r}0.2342 \\
(0.24)\end{array}$ \\
\hline Loans & $\begin{array}{r}0.6114 \\
(0.00)\end{array}$ & $\begin{array}{r}0.5276 \\
(0.04)\end{array}$ & $\begin{array}{r}0.2180 \\
(0.49)\end{array}$ & $\begin{array}{r}0.4888 \\
(0.01)\end{array}$ & $\begin{array}{r}-0.0213 \\
(0.96)\end{array}$ \\
\hline Portfolio flows & $\begin{array}{r}0.4644 \\
(0.09)\end{array}$ & $\begin{array}{r}0.4148 \\
(0.10)\end{array}$ & $\begin{array}{r}-0.7035 \\
(0.10)\end{array}$ & $\begin{array}{r}-0.6071 \\
(0.61)\end{array}$ & $\begin{array}{r}0.2064 \\
(0.41)\end{array}$ \\
\hline Growth & $\begin{array}{r}0.0521 \\
(0.05)\end{array}$ & $\begin{array}{r}0.1089 \\
(0.04)\end{array}$ & $\begin{array}{r}1.0529 \\
(0.00)\end{array}$ & $\begin{array}{r}0.2723 \\
(0.17)\end{array}$ & $\begin{array}{r}0.2075 \\
(0.20)\end{array}$ \\
\hline Change in terms of trade & $\begin{array}{r}-0.0104 \\
(0.20)\end{array}$ & $\begin{array}{r}-0.0246 \\
(0.21)\end{array}$ & $\begin{array}{r}-0.0259 \\
(0.02)\end{array}$ & $\begin{array}{r}-0.0206 \\
(0.03)\end{array}$ & $\begin{array}{r}-0.0117 \\
(0.32)\end{array}$ \\
\hline Real interest rate & $\begin{array}{r}0.0005 \\
(0.16)\end{array}$ & $\begin{array}{r}-0.0004 \\
(0.22)\end{array}$ & $\begin{array}{r}-0.0009 \\
(0.61)\end{array}$ & $\begin{array}{r}-0.0010 \\
(0.38)\end{array}$ & $\begin{array}{r}0.0000 \\
(0.97)\end{array}$ \\
\hline M2 & $\begin{array}{r}0.0850 \\
(0.05)\end{array}$ & $\begin{array}{r}0.0006 \\
(0.70)\end{array}$ & $\begin{array}{r}0.3768 \\
(0.01)\end{array}$ & $\begin{array}{r}0.0066 \\
(0.45)\end{array}$ & $\begin{array}{r}0.0023 \\
(0.51)\end{array}$ \\
\hline Uncertainty & $\begin{array}{r}0.2297 \\
(0.60)\end{array}$ & $\begin{array}{r}-0.1509 \\
(0.63)\end{array}$ & $\begin{array}{r}-1.6069 \\
(0.18)\end{array}$ & $\begin{array}{r}-0.7214 \\
(0.09)\end{array}$ & $\begin{array}{r}-0.3658 \\
(0.47)\end{array}$ \\
\hline Investment, lagged once & & & $\begin{array}{r}0.8422 \\
(0.00) \\
\end{array}$ & $\begin{array}{r}0.7284 \\
(0.00) \\
\end{array}$ & $\begin{array}{r}0.2608 \\
(0.15) \\
\end{array}$ \\
\hline Test for $1^{\text {st }}$ order serial correlation & $(0.00)$ & $(0.00)$ & $(0.00)$ & $\begin{array}{l}(0.00) \\
(079)\end{array}$ & $(0.03)$ \\
\hline $\begin{array}{l}\text { Test for } 2 \text { nd order serial correlation } \\
\text { Sargan J }\end{array}$ & $\begin{array}{l}(0.04) \\
(0.16)\end{array}$ & $\begin{array}{l}(0.69) \\
(0.43)\end{array}$ & $\begin{array}{l}(0.25) \\
(0.13)\end{array}$ & $\begin{array}{l}(0.79) \\
(0.23)\end{array}$ & $\begin{array}{l}(0.57) \\
(0.01)\end{array}$ \\
\hline
\end{tabular}

Notes. For each column p-values are reported in brackets. Columns 1 and 2 were estimated using an instrumental variables estimator. Columns 3-5 were estimated using a one-step first-difference GMM estimator attributable to Arellano and Bond (1991), using DPD98 for Gauss. The coefficients and p-values are robust to heteroscedasticity. 
Table 4 Nonlinearities in the Capital Flows-Investment Relationship: 1979-1999

\begin{tabular}{|c|c|c|c|c|c|c|}
\hline & \multicolumn{3}{|c|}{ Annual Data Dynamic Specification } & \multicolumn{3}{|c|}{ 3-year Data Static Specification } \\
\hline & $\begin{array}{l}\text { Interactions } \\
\text { with FDI }\end{array}$ & $\begin{array}{l}\text { Interactions } \\
\text { with loans }\end{array}$ & $\begin{array}{c}\text { Interactions } \\
\text { with } \\
\text { portfolio } \\
\text { flows }\end{array}$ & $\begin{array}{l}\text { Interactions } \\
\text { with FDI }\end{array}$ & $\begin{array}{l}\text { Interactions } \\
\text { with loans }\end{array}$ & $\begin{array}{c}\text { Interactions } \\
\text { with } \\
\text { portfolio } \\
\text { flows }\end{array}$ \\
\hline & 1 & 2 & 5 & 4 & 5 & 6 \\
\hline Independent variable & $\begin{array}{l}\text { Coefficient } \\
\text { (p-value) }\end{array}$ & & & & & \\
\hline Foreign direct investment & $\begin{array}{r}1.3640 \\
(0.03)\end{array}$ & $\begin{array}{r}0.5641 \\
(0.00)\end{array}$ & $\begin{array}{r}0.2956 \\
(0.19)\end{array}$ & $\begin{array}{r}0.8377 \\
(0.05)\end{array}$ & $\begin{array}{r}0.8452 \\
(0.03)\end{array}$ & $\begin{array}{r}0.7705 \\
(0.02)\end{array}$ \\
\hline Loans & $\begin{array}{r}0.7130 \\
(0.09)\end{array}$ & $\begin{array}{r}-0.3535 \\
(0.52)\end{array}$ & $\begin{array}{r}0.9949 \\
(0.01)\end{array}$ & $\begin{array}{r}0.7039 \\
(0.00)\end{array}$ & $\begin{array}{r}0.9212 \\
(0.02)\end{array}$ & $\begin{array}{r}0.6110 \\
(0.00)\end{array}$ \\
\hline Portfolio flows & $\begin{array}{r}0.0876 \\
(0.89)\end{array}$ & $\begin{array}{r}-0.2793 \\
(0.59)\end{array}$ & $\begin{array}{r}1.3546 \\
(0.47)\end{array}$ & $\begin{array}{r}0.4826 \\
(0.12)\end{array}$ & $\begin{array}{r}0.6635 \\
(0.02)\end{array}$ & $\begin{array}{r}1.1058 \\
(0.10)\end{array}$ \\
\hline Growth & $\begin{array}{r}0.3740 \\
(0.32)\end{array}$ & $\begin{array}{r}0.5192 \\
(0.02)\end{array}$ & $\begin{array}{r}0.3194 \\
(0.37)\end{array}$ & $\begin{array}{r}0.2534 \\
(0.34)\end{array}$ & $\begin{array}{r}0.1763 \\
(0.49)\end{array}$ & $\begin{array}{r}0.2308 \\
(0.35)\end{array}$ \\
\hline Change in terms of trade & $\begin{array}{r}-0.0164 \\
(0.13)\end{array}$ & $\begin{array}{r}-0.0185 \\
(0.05)\end{array}$ & $\begin{array}{r}-0.0168 \\
(0.05)\end{array}$ & $\begin{array}{r}-0.0235 \\
(0.44)\end{array}$ & $\begin{array}{r}-0.0240 \\
(0.43)\end{array}$ & $\begin{array}{r}-0.0246 \\
(0.41)\end{array}$ \\
\hline Real interest rate & $\begin{array}{r}-0.0010 \\
(0.47)\end{array}$ & $\begin{array}{r}-0.0007 \\
(0.58)\end{array}$ & $\begin{array}{r}-0.0006 \\
(0.70)\end{array}$ & $\begin{array}{r}-0.0002 \\
(0.80)\end{array}$ & $\begin{array}{r}0.0004 \\
(0.42)\end{array}$ & $\begin{array}{r}0.0002 \\
(0.68)\end{array}$ \\
\hline M2 & $\begin{array}{r}0.2438 \\
(0.10)\end{array}$ & $\begin{array}{r}0.0633 \\
(0.68)\end{array}$ & $\begin{array}{r}0.1513 \\
(0.42)\end{array}$ & $\begin{array}{r}-0.0001 \\
(0.92)\end{array}$ & $\begin{array}{r}0.0011 \\
(0.28)\end{array}$ & $\begin{array}{r}0.0014 \\
(0.16)\end{array}$ \\
\hline Uncertainty & $\begin{array}{r}-0.7096 \\
(0.17)\end{array}$ & $\begin{array}{r}-0.3272 \\
(0.18)\end{array}$ & $\begin{array}{r}-0.5010 \\
(0.17)\end{array}$ & $\begin{array}{r}-1.0740 \\
(0.05)\end{array}$ & $\begin{array}{r}-0.9980 \\
(0.10)\end{array}$ & $\begin{array}{r}-0.8502 \\
(0.11)\end{array}$ \\
\hline Financial integration & $\begin{array}{r}0.0189 \\
(0.01)\end{array}$ & $\begin{array}{r}-0.0022 \\
(0.46)\end{array}$ & $\begin{array}{r}0.0023 \\
(0.64)\end{array}$ & $\begin{array}{r}0.0109 \\
(0.27)\end{array}$ & $\begin{array}{r}-0.0015 \\
(0.76)\end{array}$ & $\begin{array}{r}0.0001 \\
(0.98)\end{array}$ \\
\hline Policy & $\begin{array}{r}-0.0080 \\
(0.30)\end{array}$ & $\begin{array}{r}-0.0098 \\
(0.20)\end{array}$ & $\begin{array}{r}-0.0131 \\
(0.05)\end{array}$ & $\begin{array}{r}-0.0666 \\
(0.00)\end{array}$ & $\begin{array}{r}-0.0571 \\
(0.01)\end{array}$ & $\begin{array}{r}-0.0545 \\
(0.00)\end{array}$ \\
\hline FlowsFinancial integration & $\begin{array}{r}-0.9041 \\
(0.00)\end{array}$ & $\begin{array}{r}0.5592 \\
(0.08)\end{array}$ & $\begin{array}{r}-0.9751 \\
(0.29)\end{array}$ & $\begin{array}{r}-0.5194 \\
(0.06)\end{array}$ & $\begin{array}{r}-0.2555 \\
(0.18)\end{array}$ & $\begin{array}{r}-0.4125 \\
(0.14)\end{array}$ \\
\hline Flows*High policy & $\begin{array}{r}1.5152 \\
(0.03)\end{array}$ & $\begin{array}{r}0.4936 \\
(0.55)\end{array}$ & $\begin{array}{r}3.4498 \\
(0.10)\end{array}$ & $\begin{array}{r}1.5147 \\
(0.00)\end{array}$ & $\begin{array}{r}0.8289 \\
(0.07)\end{array}$ & $\begin{array}{r}1.6018 \\
(0.06)\end{array}$ \\
\hline Investment, lagged once & $\begin{array}{r}0.5934 \\
(0.00) \\
\end{array}$ & $\begin{array}{r}0.5862 \\
(0.00) \\
\end{array}$ & $\begin{array}{r}0.4838 \\
(0.00) \\
\end{array}$ & & & \\
\hline Test for 1 st order serial correlation & $(0.00)$ & $(0.00)$ & $(0.00)$ & $(0.00)$ & $(0.02)$ & $(0.01)$ \\
\hline Test for 2 nd order serial correlation & $(0.20)$ & $(0.80)$ & $(0.88)$ & $(0.53)$ & $(0.18)$ & $(0.23)$ \\
\hline Sargan J & $(0.06)$ & $(0.00)$ & $(0.01)$ & $(0.79)$ & $(0.97)$ & $(0.96)$ \\
\hline
\end{tabular}

Notes. For each column p-values are reported in brackets. High policy regimes are those with a CPIArating in excess of 3.5 (upper $20^{\text {th }}$ percentile). Regressions 1-3 were estimated using the Arellano-Bond one-step first-difference GMM estimator, using DPD98 for Gauss. The coefficients and p-values are robust to heteroscedasticity. Regressions 4-6 were estimated using an instrumental variable estimator. 
Figure 1 Financial Integration, Policies and Long-Term Capital Inflows, 1977-1999

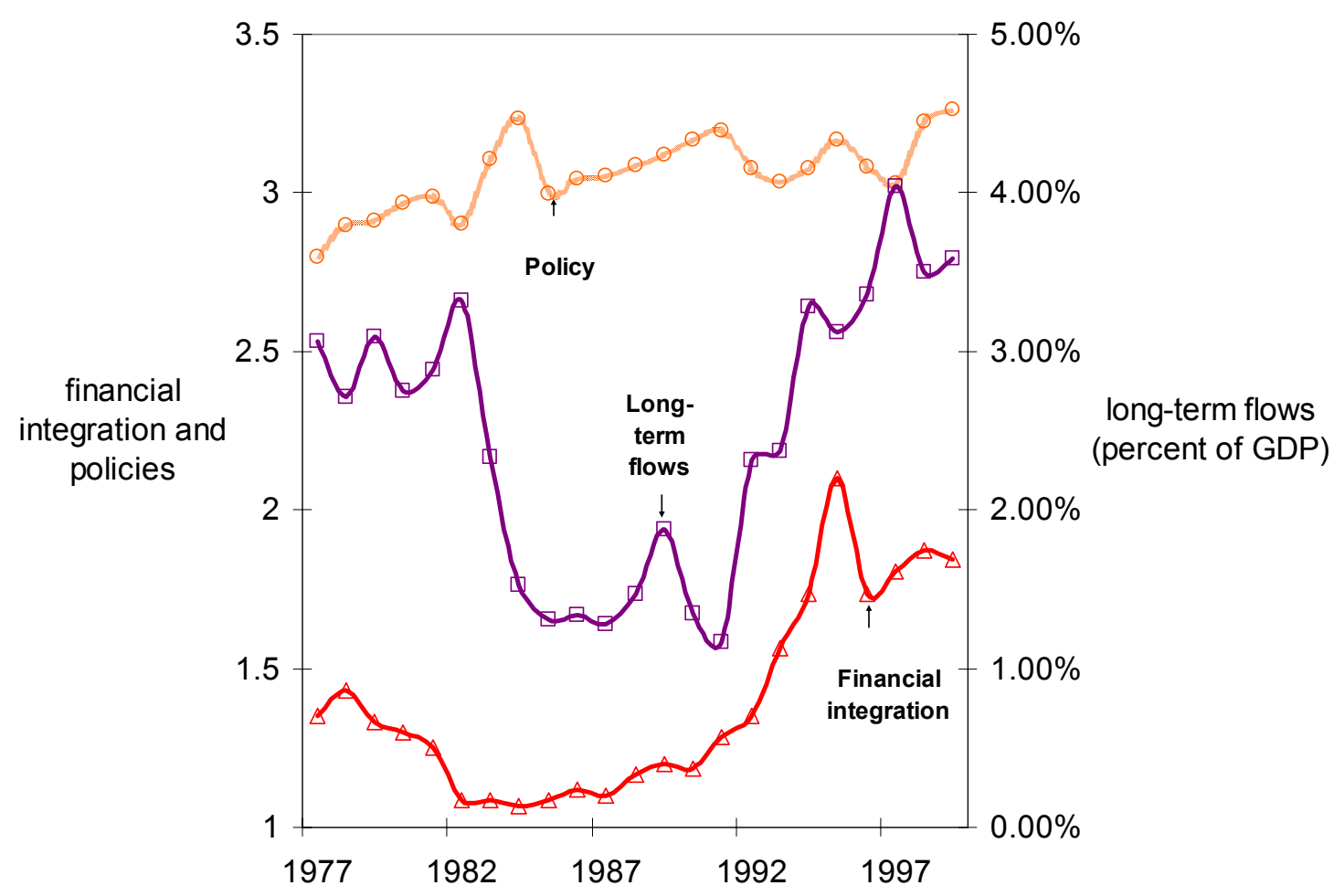

Notes. The financial integration index was constructed using four variables proxying for restrictions on the capital and current accounts. The policy index is the World Bank's Country Policy Institutional Assesment Index and long-term flows are aggregate long-term flows to developing countries reported in the Global Development Finance. See text and Appendix A2 for details. 
Figure 2 Long-Run Impact of Private Capital Flows*

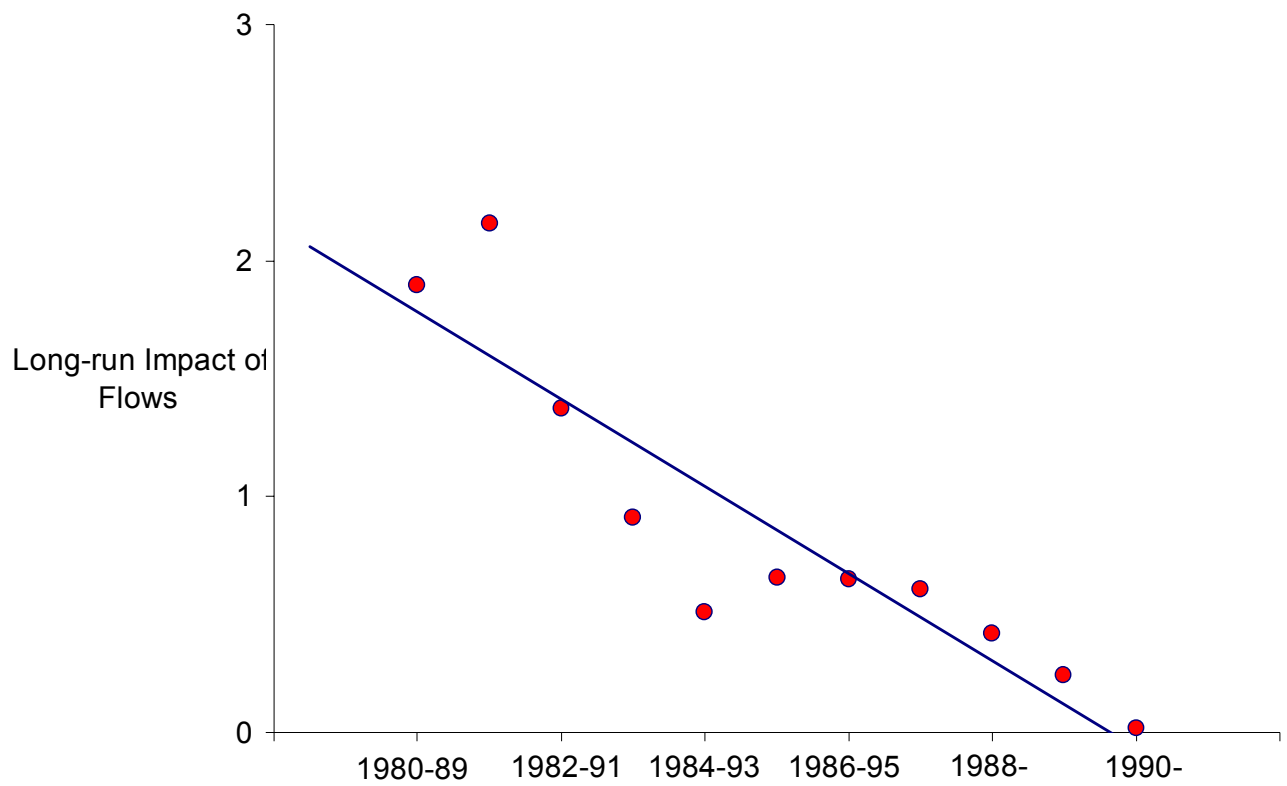

*The estimated relationships between long-run flows and investment are based on annual data over 10-year windows that are rolled forward through time. The specification is identical to that used in Table 2 column 4 . The long-run impact of flows is calculated by normalizing the coefficient on long-run flows by the coefficient on lagged investment. Estimation is based on the Arellano-Bond one-step GMM estimator. 


\title{
Endotes
}

\begin{abstract}
${ }^{1}$ One disadvantage of this variable is that it implicitly assumes that while shocks to the supply of capital are positively correlated across countries, shocks to the demand for capital are largely uncorrelated. This is a reasonable assumption, except perhaps during crisis-periods, when demand shocks are more likely to be correlated across borders. In particular a global crisis may trigger sharp declines in investment in a large sample of countries resulting in a decline in flows to developing countries as a whole.
\end{abstract}

2 The distances were obtained from Boisso and Ferrantino (1997). Gaps in the data were filled using the authors' calculations.

${ }^{3}$ The standard least-squares estimator is biased in dynamic panels and more generally when the explanatory variables are predetermined. Anderson and Hsiao (1982) suggest using lagged observations of the regressors as instruments. Specifically, the dependent variable lagged twice is a valid instrument for the first difference of the lagged dependent variable, while a lagged value of the regressors can serve as an instrument for the first difference of the regressors, when they are predetermined. Arellano and Bond (1991) propose a more efficient estimator which instruments for endogenous and predetermined variables using an increasing sequence of lagged values, thus making use of more information in the sample.

${ }^{4}$ The IFS data includes short-term flows, whereas the GDF allows a distinction between short-term and long-term flows (the GDF definition of short-term debt is the debt with an original maturity of less than one year). The GDF data reports only those transactions denominated in foreign currencies.

${ }^{5}$ This is the opposite of the convention of treating a 1 as a restriction and a 0 as the lack of restrictions.

${ }^{6}$ An important change occurred in the measurement of the intensity of controls on the capital account starting in 1996, when the IMF's Exchange Arrangements and Restrictions stopped reporting the summary measure and started reporting details on several aspects of the capital account, which permitted the construction of a graded index of capital account restrictions rather than a dichotomous variable, as in the past. Thus the financial integration index from 1996 onward is not entirely comparable to earlier years. It is, moreover, the case that in 1996 the average value of the financial integration index shows a marked decline (Figure 1). However closer scrutiny reveals that this drop in financial integration is driven not by the capital accounts measure but almost entirely by a sharp decrease in the current account transactions measure, which had earlier risen sharply in 1995. Moreover, sensitivity analysis using a sample truncated in 1995 did not qualitatively change our results. 
${ }^{7}$ Quinn (1997) has also constructed a continuous measure of capital controls based on the details provided in the IMF publication. However, this index is available only for a few years. Moreover, Chinn (2002) regresses the Quinn index on the four measures used to construct our index and finds that they explain 71 percent of the variation in that index.

${ }^{8}$ See Country Policy and Institutional Assessment 2001 Questionnaire for a detailed discussion (http://www.worldbank.org/ida/cpiaq2001.pdf).

${ }^{9}$ Bosworth and Collins (1999) use two lags of growth rates in their specification. However, our approach is to treat each variable as endogenous and estimate the resulting model using an appropriate set of instruments. Consequently none of the variables enter with lags. Nevertheless, if we employ a specification identical to that in Bosworth and Collins (1999), our results remain largely unaltered.

${ }^{10}$ Our sample of developed countries consists of the original OECD member nations, with the exception of Turkey, which enters in our sample of developing countries. In addition, our sample includes the following countries: Australia, Finland, Japan and New Zealand, which are also presently members of the OECD, and Norway, which is not a member. Data were obtained primarily from International Financial Statistics and the World Development Indicators.

${ }^{11}$ First-order serial correlation is to be expected as this simply an artifact of firstdifferencing.

12 This measure was originally proposed by Lane and Milesi-Ferretti (2002). 